\title{
Effects of Annealing Temperature on Optical Band Gap of Sol-gel Tungsten Trioxide Films
}

\author{
Guanguang Zhang, Kuankuan Lu, Xiaochen Zhang, Weijian Yuan, Muyang Shi, \\ Honglong Ning * (D), Ruiqiang Tao, Xianzhe Liu, Rihui Yao * (D) and Junbiao Peng
}

Institute of Polymer Optoelectronic Materials and Devices, State Key Laboratory of Luminescent Materials and Devices, South China University of Technology, Guangzhou 510640, China; msgg-zhang@mail.scut.edu.cn (G.Z.); mskk-lu@mail.scut.edu.cn (K.L.); mszhang_xc@mail.scut.edu.cn (X.Z.); 201430320366@mail.scut.edu.cn (W.Y.); 201430320229@mail.scut.edu.cn (M.S.);

201510102158@mail.scut.edu.cn (R.T.); msliuxianzhe@mail.scut.edu.cn (X.L.); psjbpeng@scut.edu.cn (J.P.)

* Correspondence: ninghl@scut.edu.cn (H.N.); yaorihui@scut.edu.cn (R.Y.); Tel.: +86-20-8711-4525 (H.N.)

Received: 6 July 2018; Accepted: 25 July 2018; Published: 30 July 2018

\begin{abstract}
Tungsten trioxide $\left(\mathrm{WO}_{3}\right)$ is a wide band gap semiconductor material that is used as an important electrochromic layer in electrochromic devices. In this work, the effects of the annealing temperature on the optical band gap of sol-gel $\mathrm{WO}_{3}$ films were investigated. X-ray Diffraction (XRD) showed that $\mathrm{WO}_{3}$ films were amorphous after being annealed at $100{ }^{\circ} \mathrm{C}, 200{ }^{\circ} \mathrm{C}$ and $300{ }^{\circ} \mathrm{C}$, respectively, but became crystallized at $400^{\circ} \mathrm{C}$ and $500^{\circ} \mathrm{C}$. An atomic force microscope (AFM) showed that the crystalline $\mathrm{WO}_{3}$ films were rougher than the amorphous $\mathrm{WO}_{3}$ films (annealed at $200{ }^{\circ} \mathrm{C}$ and $300{ }^{\circ} \mathrm{C}$ ). An ultraviolet spectrophotometer showed that the optical band gap of the $\mathrm{WO}_{3}$ films decreased from $3.62 \mathrm{eV}$ to $3.30 \mathrm{eV}$ with the increase in the annealing temperature. When the $\mathrm{Li}^{+}$ was injected into $\mathrm{WO}_{3}$ film in the electrochromic reaction, the optical band gap of the $\mathrm{WO}_{3}$ films decreased. The correlation between the optical band gap and the electrical properties of the $\mathrm{WO}_{3}$ films was found in the electrochromic test by analyzing the change in the response time and the current density. The decrease in the optical band gap demonstrates that the conductivity increases with the corresponding increase in the annealing temperature.
\end{abstract}

Keywords: optical band gap; tungsten trioxide film; annealing temperature; electrochromism

\section{Introduction}

Tungsten trioxide $\left(\mathrm{WO}_{3}\right)$ is an important indirect band gap semiconductor material [1]. It is used as a functional layer in the applications of gas sensors [2], photocatalysis [3], solar cells [4], water splitting [5] and electrochromism [6]. Electrochromic devices, such as smart windows [7], can meet the market demand of energy-saving devices. Since $\mathrm{WO}_{3}$ 's electrochromic properties were found, researchers have widely studied $\mathrm{WO}_{3}$-based electrochromic thin films and device applications [8].

There are various choices for preparing $\mathrm{WO}_{3}$ films with the development of thin film technology. These include sputtering [9], chemical vapor deposition [10], vacuum evaporation [11], and sol-gel [12], among others. Currently, magnetron sputtering is a commercial technology that is used to prepare $\mathrm{WO}_{3}$ films due to its uniformity of film and reliability. However, the high cost issue and problems in preparing large-size devices cannot be ignored. The sol-gel method is a feasible technology for reducing the cost even, though there are still some problems at the present stage, such as film inhomogeneity and poor process repeatability, among others. With the development of new sol-gel techniques, such as inkjet printing [13], sol-gel technology is promising for commercial applications in the future.

The optical and electrical properties of $\mathrm{WO}_{3}$ film are related to the parameters of the sol-gel technique, such as the solvent [14], precursor [15] and annealing temperature [16], among others. 
In previous work, there was a significant difference in the band gap of the $\mathrm{WO}_{3}$ films obtained using different processes $[17,18]$. Therefore, it is worthwhile to launch further investigations into the relationship between band gap and the optical and electrical properties of $\mathrm{WO}_{3}$ films, especially in regards to electrochromic properties. In this paper, we conducted a study on the optical band gap of $\mathrm{WO}_{3}$ films with different annealing temperatures. The crystallinity, response time morphology and conductivity were also analyzed together. A correlation between the optical band gap and the electrical properties (conductivity) was found.

\section{Materials and Methods}

Tungsten powder (W, 99.5\% metals basis, Macklin Biochemical Co. Ltd, Shanghai, China) and hydrogen peroxide $\left(\mathrm{H}_{2} \mathrm{O}_{2}\right.$, Hydrogen peroxide $30 \%$, Guangzhou chemical regent factory, Guangzhou, China) were mixed in a beaker with a water bath at $25^{\circ} \mathrm{C}$. After the reaction finished, an evaporative concentration treatment (at $150^{\circ} \mathrm{C}$ ) was conducted to remove the surplus $\mathrm{H}_{2} \mathrm{O}_{2}$. Finally, an appropriate anhydrous ethanol was added into the concentrated solution and the mixed solution was sealed and stirred for $3 \mathrm{~h}$ at $70{ }^{\circ} \mathrm{C}$ to obtain the sol-gel. A spin coating technique was used to prepare the $\mathrm{WO}_{3}$ films (around $80 \mathrm{~nm}$ ) on the indium tin oxide (ITO) glass. The thickness of the $\mathrm{WO}_{3}$ film was optimized and controlled by the concentration of solution and spin coating parameters and it had an important influence on the electrochromic transmittance modulation ability [19]. In this work, the annealing temperature was focused on and other unrelated variables (sol concentration, spin coating parameters, substrate, electrolyte, etc.) were controlled. These as-deposited films were annealed at $100{ }^{\circ} \mathrm{C}, 200{ }^{\circ} \mathrm{C}$, $300{ }^{\circ} \mathrm{C}, 400{ }^{\circ} \mathrm{C}$ and $500{ }^{\circ} \mathrm{C}$ for $60 \mathrm{~min}$, respectively.

The crystallization of the film was analyzed by X-ray Diffraction (XRD, PANalytical Empyrean DY1577, PANalytical, Almelo, The Netherlands). The surface morphology was measured by atomic force microscopy (AFM, Being Nano-Instruments BY3000 Being Nano-Instruments, Beijing, China). The electrochromic test was performed using $0.8 \mathrm{~mol} / \mathrm{L}$ of lithium perchlorate/propylene carbonate $\left(\mathrm{LiClO}_{4} / \mathrm{PC}\right)$ electrolyte and an electrode gap $(\sim 1 \mathrm{~mm})$. The transmission spectra were measured by an Ultraviolet spectrophotometer (SHIMADZU UV2600, SHIMADZU, Tokyo, Japan), with ITO glass (Optical band gap: $>4 \mathrm{eV}$ ) acting as a blank. The current of the electrochromic test was recorded by an electrochemical workstation (CH Instruments $\mathrm{CHI600E}, \mathrm{CH}$ Instruments, Shanghai, China). The relationship between the change of transmittance and the time was measured by a micro-spectrometer (Morpho PG2000, Morpho, Shanghai, China), with ITO glass acting as a blank.

\section{Results and Discussions}

Figure 1 illustrates the X-ray patterns of the $\mathrm{WO}_{3}$ films that were annealed at different temperatures. The crystalline structures of these films were further analyzed using Jade 6.0 and PDF\#30-1387 and PDF\#41-0905. In Figure 1a, there are diffraction peaks of $\mathrm{WO}_{3}$ at the patterns of the $\mathrm{WO}_{3}$ films annealed at $400{ }^{\circ} \mathrm{C}$ and $500{ }^{\circ} \mathrm{C}$, which demonstrate that these films transformed from amorphous to crystalline when the annealing temperature is higher than $400{ }^{\circ} \mathrm{C}$. Furthermore, the change of crystalline structure was analyzed in Figure $1 \mathrm{~b}$. The characteristic diffraction peaks of $\mathrm{WO}_{3}$ films $\left(400{ }^{\circ} \mathrm{C}\right)$ indicate that the $\mathrm{WO}_{3}$ films initially transform from an amorphous to a monoclinic structure. When the annealing temperature reached $500{ }^{\circ} \mathrm{C}$, there was only one diffraction peak of the $\mathrm{WO}_{3}$ film in the range of $2 \theta\left(22^{\circ}\right.$ to $\left.26^{\circ}\right)$, which demonstrated that the monoclinic structure of the $\mathrm{WO}_{3}$ films turned into a cubic structure. Strictly speaking, the stoichiometric ratio of tungsten and oxygen was not fully satisfied with 1:3. Therefore, there was an oxygen vacancy which influenced the optical and electrical properties of $\mathrm{WO}_{3}$ films [20]. 


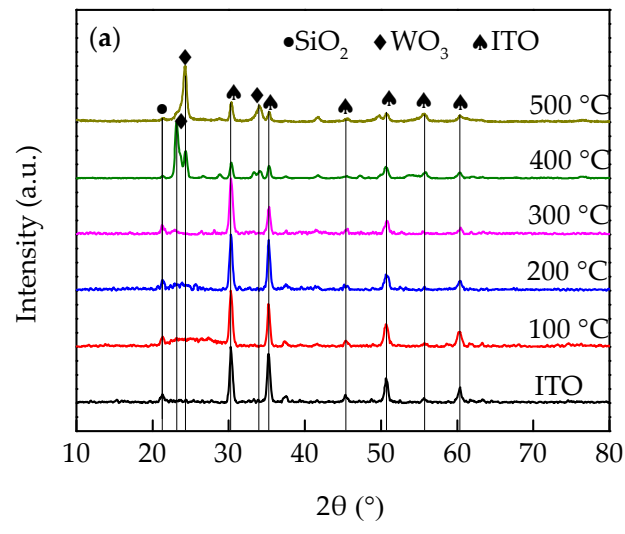

(a)

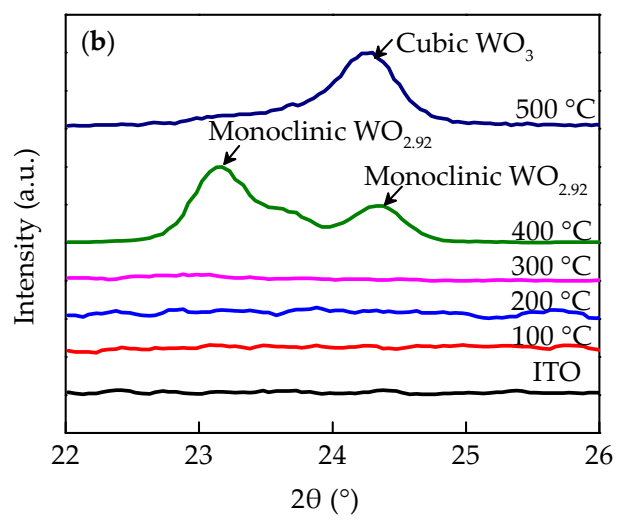

(b)

Figure 1. X-ray patterns of $\mathrm{WO}_{3}$ films annealed at different temperature. (a) The XRD patterns in a large range of $2 \theta\left(10^{\circ}\right.$ to $\left.80^{\circ}\right)$; (b) The XRD patterns in a small range of $2 \theta\left(22^{\circ}\right.$ to $\left.26^{\circ}\right)$. The amorphous $\mathrm{WO}_{3}$ transformed into monoclinic structure and cubic structure at $400{ }^{\circ} \mathrm{C}$ and $500{ }^{\circ} \mathrm{C}$, respectively.

The surface morphology of these films was measured by AFM and the results are shown in Figure 2. Figure $2 \mathrm{f}$ shows a comparison of the roughness of these films at different annealing temperatures. The surface of the $\mathrm{WO}_{3}$ film that was annealed at $100{ }^{\circ} \mathrm{C}$ is rougher than other films, which is confirmed by Figure $2 \mathrm{a}$ and its roughness. In this work, the solvent of sol was ethanol and water, which has a boiling point of around $80{ }^{\circ} \mathrm{C}$. The $100{ }^{\circ} \mathrm{C}$ annealing treatment can remove the solvent, but it is not enough to remove the bound water in the tungsten acid [21]. In addition, solvent evaporation can cause defects in the surface, such as pores [22], and there is not enough energy to reduce these defects during annealing treatment. Therefore, among these samples, the $\mathrm{WO}_{3}$ film annealed at $100{ }^{\circ} \mathrm{C}$ had the highest roughness.

The roughness of the films annealed at $200{ }^{\circ} \mathrm{C}$ and $300{ }^{\circ} \mathrm{C}$ was around $1.9 \mathrm{~nm}$, which is less than that of the films (around $3.3 \mathrm{~nm}$ ) annealed at $400{ }^{\circ} \mathrm{C}$ and $500{ }^{\circ} \mathrm{C}$. This demonstrated that the crystalline film was rougher than the amorphous film because of its grain growth at a high temperature. The change in roughness indirectly revealed that the change in the $\mathrm{WO}_{3}$ film composition and crystalline structure was due to the increase in the annealing temperature, which is consistent with the results of XRD.
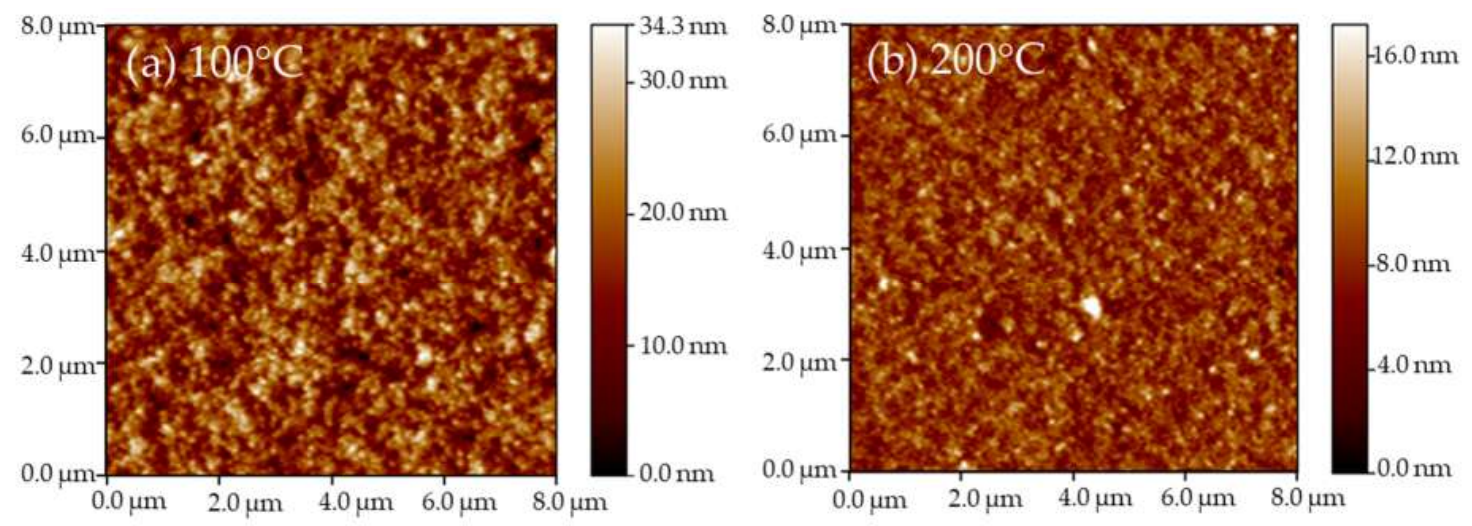

Figure 2. Cont. 

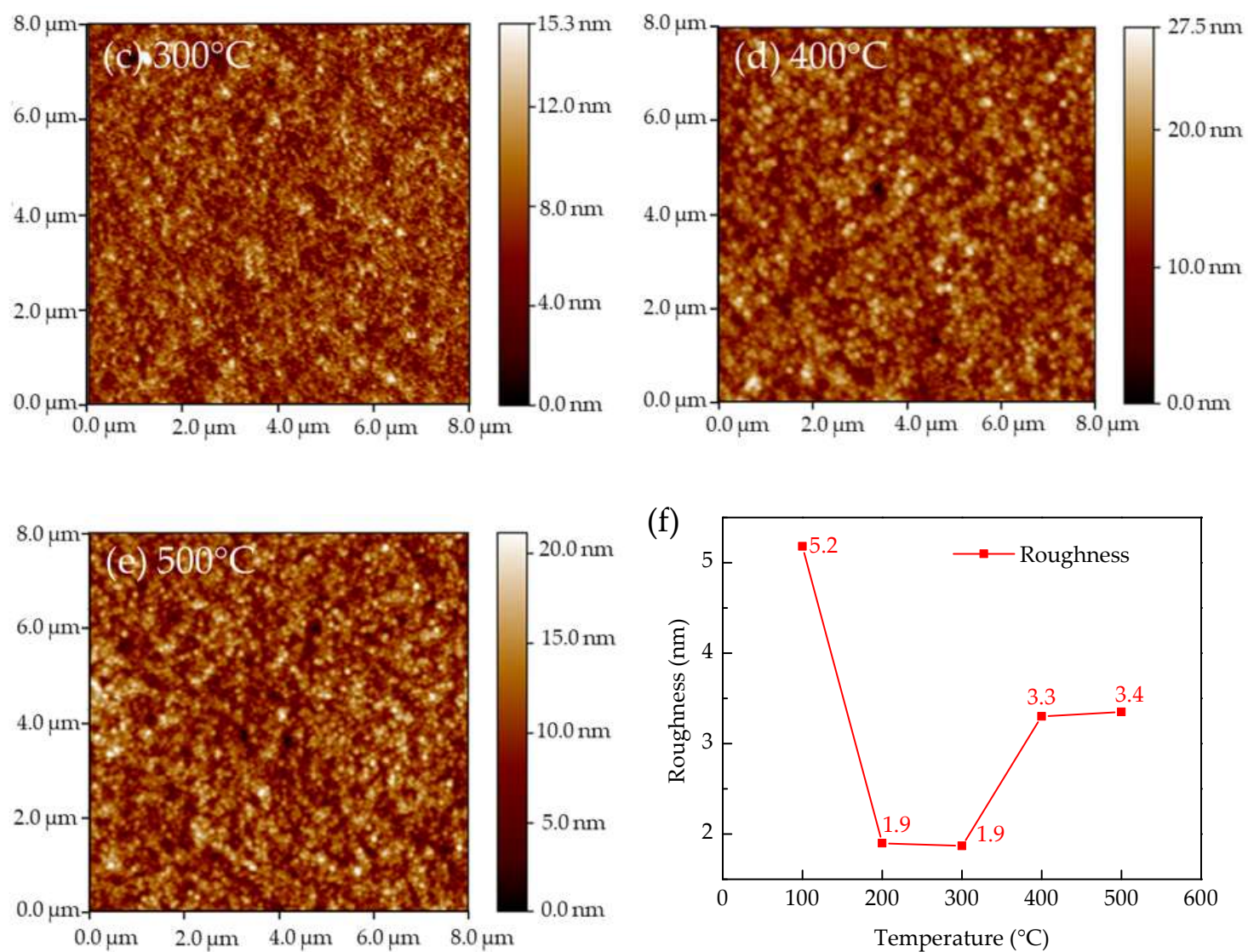

Figure 2. The atomic force microscope (AFM) images $8000 \mathrm{~nm} \times 8000 \mathrm{~nm}$ ) and the roughness of $\mathrm{WO}_{3}$ films. (a) $100{ }^{\circ} \mathrm{C}$; (b) $200{ }^{\circ} \mathrm{C}$; (c) $300{ }^{\circ} \mathrm{C}$; (d) $400{ }^{\circ} \mathrm{C}$; (e) $500{ }^{\circ} \mathrm{C}$; (f) the roughness of $\mathrm{WO}_{3}$ films, which are read by the support software of AFM.

The band gap of $\mathrm{WO}_{3}$ film can be measured and analyzed by an ultraviolet spectrophotometer. The optical band gap is distinguished from the band gap measured by other methods. According to Equation (1), the optical band gap can be calculated [23].

$$
\alpha h v=A\left(h v-E_{g}\right)^{n}
$$

where $\alpha$ is the absorption coefficient, which can be measured by the ultraviolet spectrophotometer; $h$ is the Planck constant; $v$ is the light frequency; $A$ is a proportionality constant; $E_{g}$ is the optical band gap; and $n$ is a number which is $1 / 2$ for the direct band gap semiconductor and 2 for the indirect band gap semiconductor. In this work, $n$ is 2 because the $\mathrm{WO}_{3}$ was an indirect band gap semiconductor.

To further investigate the electrochromic effects on the optical band gap of $\mathrm{WO}_{3}$ film, the optical band gap of $\mathrm{WO}_{3}$ film in a bleached state and colored state were analyzed. Electrochromism involves an electrochemical reaction, as shown in Equation (2) [24]:

$$
\mathrm{WO}_{3} \text { (colorless) }+\mathrm{xLi}^{+}+\mathrm{xe}^{-} \leftrightarrow \mathrm{Li}_{x} \mathrm{WO}_{3} \text { (blue) }
$$

At its bleached state, the $\mathrm{WO}_{3}$ film is colorless. When both $\mathrm{Li}^{+}$and the electron are injected into the $\mathrm{WO}_{3}$ film under an applied voltage, the bleached state of $\mathrm{WO}_{3}$ turns into a colored state due to the generation of blue $\mathrm{Li}_{x} \mathrm{WO}_{3}$.

Figure 3a-e illustrates the curves of $(\alpha h v)^{1 / 2}$ versus the photon energy $h v$, which are calculated using the transmission spectra of the $\mathrm{WO}_{3}$ films in the colored state and the bleached state. $E_{g}$ can be extracted through the onset of the optical transitions of the $\mathrm{WO}_{3}$ films near the band edge, which is 
equal to the value of the fitting line intercepts. Figure $3 \mathrm{f}$ shows a comparison of the optical band gap value of the $\mathrm{WO}_{3}$ film that were annealed at different temperatures and electrochromic state (colored and bleached) and it indicates that the $E_{g}$ of bleached $\mathrm{WO}_{3}$ films decreases from $3.58 \mathrm{eV}$ to $3.3 \mathrm{eV}$ as the annealing temperature increases. Similarly, the $E_{g}$ of the colored $\mathrm{WO}_{3}$ film tends to decrease with an increased annealing temperature. In addition, the $E_{g}$ of all the colored $\mathrm{WO}_{3}$ films was less than that of their respective bleached $\mathrm{WO}_{3}$ films.
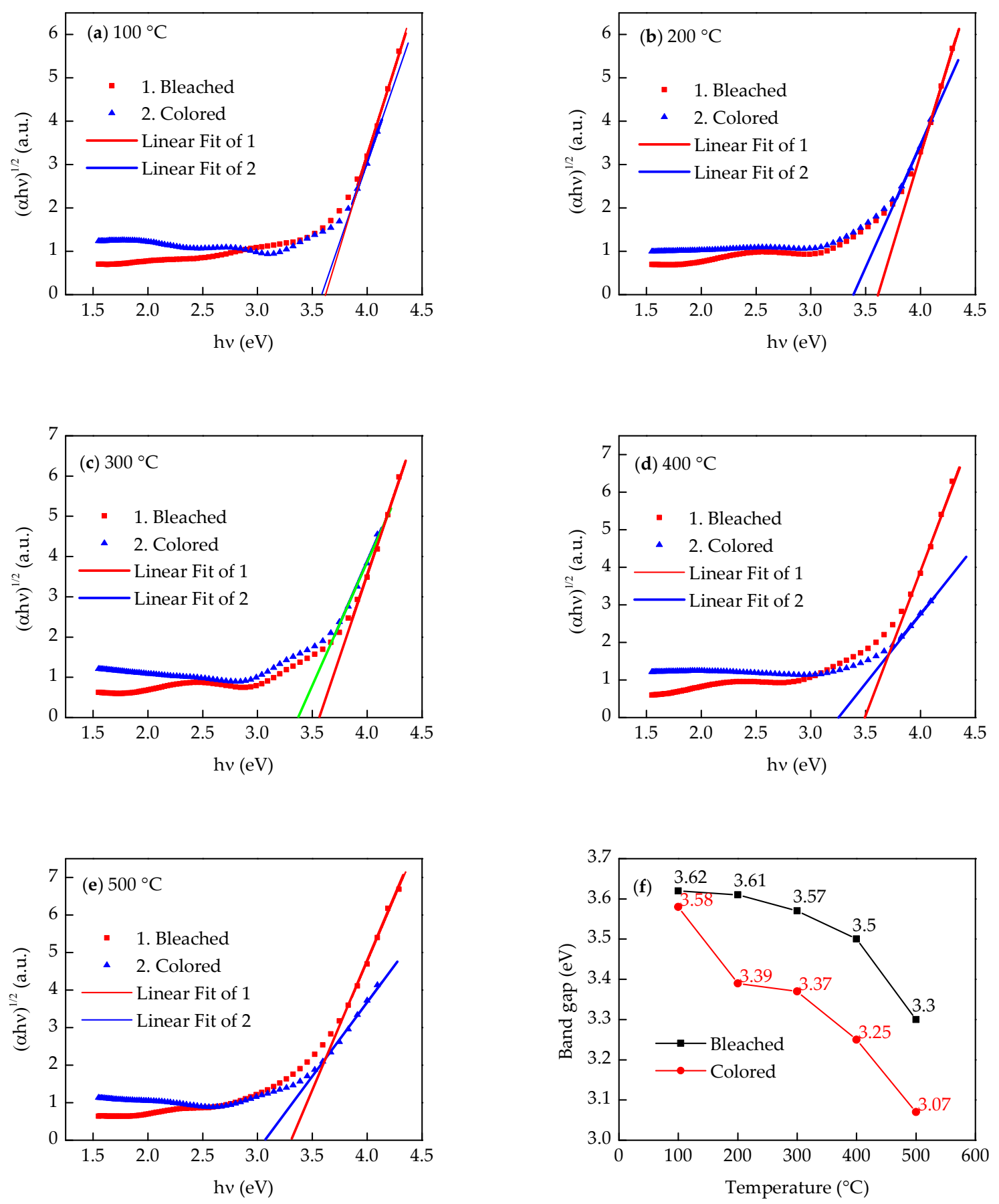

Figure 3. Optical band gap energy of $\mathrm{WO}_{3}$ films in a colored state and bleached state. (a) $100{ }^{\circ} \mathrm{C}$; (b) $200{ }^{\circ} \mathrm{C}$; (c) $300{ }^{\circ} \mathrm{C}$; (d) $400{ }^{\circ} \mathrm{C}$; (e) $500{ }^{\circ} \mathrm{C}$; and (f) a comparison of optical band gap energy of $\mathrm{WO}_{3}$ films annealed at different temperature and electrochromic state (colored and bleached). 
As for $E_{g}$, which decreased when the annealing temperature increased, a reasonable explanation was that as the annealing temperature increased, the oxygen vacancies increased, which may have provided free electrons and enhanced the conductivity of the $\mathrm{WO}_{3}$ films [25].

To further investigate the relationship between $E_{g}$, conductivity, and electrochromic response time, an electrochromic test was conducted. Figure $4 \mathrm{a}, \mathrm{b}$ illustrates the current density of the different $\mathrm{WO}_{3}$ films and the change of transmittance (at $600 \mathrm{~nm}$ ) under $\pm 2.5 \mathrm{~V}$ voltage, respectively. The peak current density of these films in the coloring process increased when the annealing temperature increased (an increase from $2.6 \mathrm{~mA} / \mathrm{cm}^{2}$ at $100{ }^{\circ} \mathrm{C}$ to $16.1 \mathrm{~mA} / \mathrm{cm}^{2}$ at $500{ }^{\circ} \mathrm{C}$ ). This indicated that the conductivity enhanced with the increase in the annealing temperature. Similarly, the peak current density of these films in the bleaching process shows a similar change (increase from $11.0 \mathrm{~mA} / \mathrm{cm}^{2}$ at $100{ }^{\circ} \mathrm{C}$ to $22.2 \mathrm{~mA} / \mathrm{cm}^{2}$ at $500{ }^{\circ} \mathrm{C}$ ). These were attributed to the decrease of $E_{g}$ and the increase of free electrons. In addition, Figure $4 \mathrm{a}$ illustrates that the peak current density of the bleaching process was larger than that of coloring process, which results from the good conductivity of $\mathrm{Li}_{\mathrm{x}} \mathrm{WO}_{3}$ [26]. This is related to the decrease of $E_{g}$ after $\mathrm{WO}_{3}$ film coloring.

Figure $4 \mathrm{~b}$ illustrates an intuitive change of transmittance response curves. The response time is defined by the time corresponding to $90 \%$ of the total transmittance change. Figure 5 shows a specific comparison of the response time in the electrochromic test. The curve of the bleaching response time in Figure 5 shows that the bleaching response time increases from $1.2 \mathrm{~s}$ to $22.7 \mathrm{~s}$, when the annealing temperature increased. In the bleaching process, the applied voltage drop is mainly across the electrolyte and the $\mathrm{Li}_{x} \mathrm{WO}_{3}$ layer. The extraction of $\mathrm{Li}^{+}$depends largely on the voltage across the $\mathrm{Li}_{\mathrm{x}} \mathrm{WO}_{3}$ layer [27]. The $E_{g}$ of the $\mathrm{WO}_{3}$ film at the colored state reduced with the increase in the annealing temperature, which was attributed to the increase in the number of free electrons. In other words, the conductivity enhanced with the increase in annealing temperature. Therefore, the voltage across the $\mathrm{Li}_{\mathrm{x}} \mathrm{WO}_{3}$ layer reduced with the increase in annealing temperature, which resulted in the increase of the bleaching response time. However, there was no similar trend in the coloring response time. The influence factors are not only the conductivity of the $\mathrm{WO}_{3}$ film, but also the interface barrier of electrolyte-film [28]. The coloring response time increased when the $\mathrm{WO}_{3}$ film changed from amorphous into crystalline, which resulted from the decrease in the voltage drop at the $\mathrm{WO}_{3}$ layers, due to the increase in the conductivity.The band gap mainly influenced the transmission of the electrons, but the transmission of $\mathrm{Li}^{+}$depended more on the structure of films (such as crystallinity, morphology, etc.) [29].

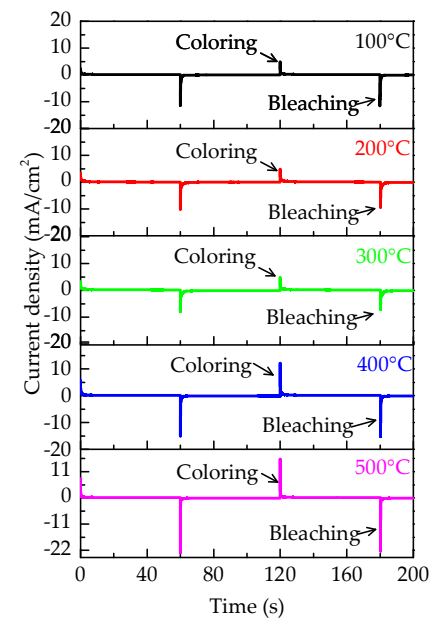

(a)

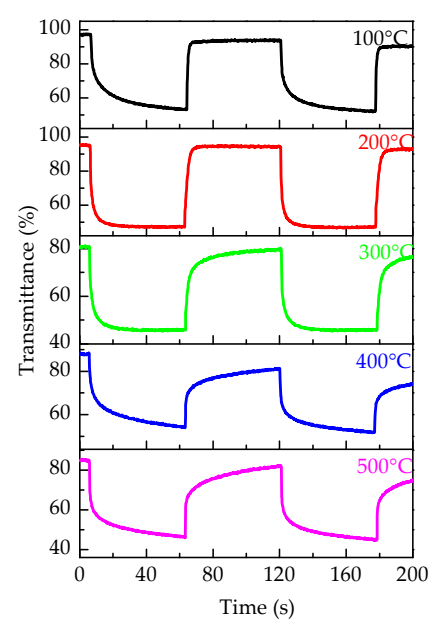

(b)

Figure 4. (a) Current change of $\mathrm{WO}_{3}$ films at different annealing temperature. The applied voltage was $\pm 2.5 \mathrm{~V}$ and the $\mathrm{WO}_{3}$ films were placed in the cathode; (b) change of transmittance (at $600 \mathrm{~nm}$ ) of $\mathrm{WO}_{3}$ films at different annealing temperature. 


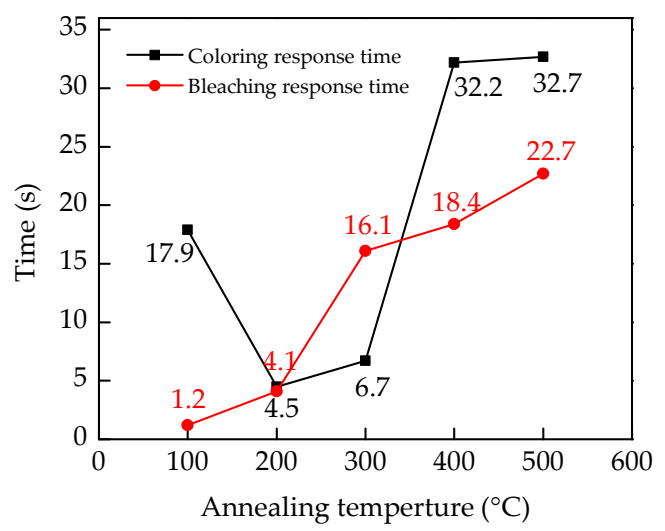

Figure 5. The curves of coloring and bleaching response time versus annealing temperature. The time corresponding to $90 \%$ of the total transmittance change is defined as the electrochromic response time.

\section{Conclusions}

The effects of the annealing temperature on the $E_{g}$ of the $\mathrm{WO}_{3}$ films were investigated. When the annealing temperature was higher than $400{ }^{\circ} \mathrm{C}$, the crystalline structure of the $\mathrm{WO}_{3}$ film changed from amorphous to monoclinic $\left(400{ }^{\circ} \mathrm{C}\right)$, and then to cubic $\left(500^{\circ} \mathrm{C}\right)$. The $E_{g}$ of the $\mathrm{WO}_{3}$ films decreased from $3.62 \mathrm{eV}$ to $3.30 \mathrm{eV}$ when the annealing temperature was increased. In addition, the $E_{g}$ of the colored $\mathrm{WO}_{3}$ films was less than that of the bleached $\mathrm{WO}_{3}$ films. The relationship between the $E_{g}$, conductivity, and electrochromic response time of the $\mathrm{WO}_{3}$ film with different annealing temperatures demonstrates that the conductivity of the $\mathrm{WO}_{3}$ film enhanced with the decrease in $E_{g}$, while the high conductivity increased the electrochromic response time.

Author Contributions: Conceptualization, G.Z.; Data curation, G.Z., K.L., W.Y., M.S. and X.L.; Formal analysis, G.Z., K.L., W.Y., R.T. and X.L.; Funding acquisition, H.N. and R.Y.; Investigation, X.Z. and M.S.; Methodology, X.Z., R.T. and X.L.; Project administration, H.N., R.Y. and J.P.; Supervision, H.N.; Writing—original draft, G.Z.; Writing一review \& editing, K.L., H.N., R.T., X.L., R.Y. and J.P.

Acknowledgments: This work was supported by National Natural Science Foundation of China (Grant.51771074, 51521002 and U1601651), National Key R\&D Program of China (No.2016YFB0401504 and 2016YFF0203600), National Key Basic Research and Development Program of China (973 program, Grant No.2015CB655004) Founded by Ministry of Science and Technology (MOST), Guangdong Natural Science Foundation (No.2016A030313459 and 2017A030310028), Guangdong Science and Technology Project (No.2016B090907001, 2016A040403037, 2016B090906002, 2017B090907016 and 2017A050503002), Guangzhou Science and Technology Project (201804020033).

Conflicts of Interest: The authors declare no conflicts of interest.

\section{References}

1. Hill, J.C.; Choi, K.S. Effect of electrolytes on the selectivity and stability of n-type $\mathrm{WO}_{3}$ photoelectrodes for use in solar water oxidation. J. Phys. Chem. C 2012, 116, 7612-7620. [CrossRef]

2. Leidinger, M.; Huotari, J.; Sauerwald, T.; Lappalainen, J.; Schütze, A. Selective detection of naphthalene with nanostructured $\mathrm{WO}_{3}$ gas sensors prepared by pulsed laser deposition. J. Sens. Sens. Syst. 2016, 5, 147-156. [CrossRef]

3. Sotelo-Vazquez, C.; Quesada-Cabrera, R.; Ling, M.; Scanlon, D.O.; Kafizas, A.; Thakur, P.K.; Lee, T.L.; Taylor, A.; Watson, G.W.; Palgrave, R.G. Photocatalysis: Evidence and effect of photogenerated charge transfer for enhanced photocatalysis in $\mathrm{WO}_{3} / \mathrm{TiO}_{2}$ heterojunction films: A computational and experimental study. Adv. Funct. Mater. 2017, 27, 1605413. [CrossRef]

4. Hara, K.; Zhao, Z.G.; Cui, Y.; Miyauchi, M.; Miyashita, M.; Mori, S. Nanocrystalline electrodes based on nanoporous-walled $\mathrm{WO}_{3}$ nanotubes for organic-dye-sensitized solar cells. Langmuir 2011, 27, 12730-12736. [CrossRef] [PubMed]

5. Wang, F.; Valentin, C.D.; Pacchioni, G. Doping of $\mathrm{WO}_{3}$ for photocatalytic water splitting: Hints from density functional theory. J. Phys. Chem. C 2012, 116, 8901-8909. [CrossRef] 
6. Cai, G.; Cui, M.; Kumar, V.; Darmawan, P.; Wang, J.; Wang, X.; Eh, L.S.; Qian, K.; Lee, P.S. Ultra large optical modulation of electrochromic porous $\mathrm{WO}_{3}$ film and the local monitoring of redox activity. Chem. Sci. 2016, 7, 1373-1382. [CrossRef] [PubMed]

7. Yang, W.; Runnerstrom, E.L.; Milliron, D.J. Switchable materials for smart windows. Annu. Rev. Chem. Biomol. Eng. 2016, 7, 283-304.

8. Granqvist, C.G. Electrochromic tungsten oxide films: Review of progress 1993-1998. Sol. Energy Mat. Sol. Cells 2000, 60, 201-262. [CrossRef]

9. Lemire, C.; Lollman, D.B.B.; Mohammad, A.A.; Gillet, E.; Aguir, K. Reactive R.F. magnetron sputtering deposition of $\mathrm{WO}_{3}$ thin films. Sens. Actuators B Chem. 2002, 84, 43-48. [CrossRef]

10. Davazoglou, D.; Leveque, G.; Donnadieu, A. Study on the optical and electrochromic properties of polycrystalline $\mathrm{WO}_{3}$ thin films prepared by CVD. Sol. Energy Mater. 1988, 17, 379-390. [CrossRef]

11. Reichman, B.; Bard, A.J. The Electrochromic process at $\mathrm{WO}_{3}$ electrodes prepared by vacuum evaporation and anodic oxidation of W. J. Electrochem. Soc. 2016, 126, 583-591. [CrossRef]

12. Zayim, E.O. Optical and electrochromic properties of sol-gel made anti-reflective $\mathrm{WO}_{3}-\mathrm{TiO}_{2}$ films. Sol. Energy Mate. Sol. Cells 2005, 87, 695-703. [CrossRef]

13. Wojcik, P.; Cruz, A.; Santos, L.; Pereira, L.; Martins, R.; Fortunato, E. Microstructure control of dual-phase inkjet-printed a- $\mathrm{WO}_{3} / \mathrm{TiO}_{2} / \mathrm{WO}_{\mathrm{X}}$ films for high-performance electrochromic applications. J. Mater. Chem. 2012, 22, 13268-13278. [CrossRef]

14. Santos, L.; Wojcik, P.; Pinto, J.V.; Elangovan, E.; Viegas, J.; Pereira, L.; Martins, R.; Fortunato, E. Structure and morphologic influence of $\mathrm{WO}_{3}$ nanoparticles on the electrochromic performance of dual-phase a- $\mathrm{WO}_{3} / \mathrm{WO}_{3}$ inkjet printed films. Adv. Electron. Mater. 2015, 1, 1-2. [CrossRef]

15. Mukherjee, R.; Sahay, P.P. Effect of precursors on the microstructural, optical, electrical and electrochromic properties of $\mathrm{WO}_{3}$ nanocrystalline thin films. J. Mater. Sci-Mater. Electron. 2015, 26, 1-13. [CrossRef]

16. Chai, Y.N.; Razak, K.A.; Lockman, Z. Effect of annealing on acid-treated $\mathrm{WO}_{3} \cdot \mathrm{H}_{2} \mathrm{O}$ nanoplates and their electrochromic properties. Electrochimica Acta 2015, 178, 673-681.

17. Gonzalez-Borrero, P.P.; Sato, F.; Medina, A.N.; Baesso, M.L.; Bento, A.C.; Baldissera, G.; Persson, C.; Niklasson, G.A.; Granqvist, C.G.; Silva, A.J.D. Optical band-gap determination of nanostructured $\mathrm{WO}_{3}$ film. Appl. Phys. Lett. 2010, 96, 201. [CrossRef]

18. Vemuri, R.S.; Engelhard, M.H.; Ramana, C.V. Correlation between surface chemistry, density, and band gap in nanocrystalline $\mathrm{WO}_{3}$ thin films. ACS Appl.Mater. Interfaces 2012, 4, 1371-1377. [CrossRef] [PubMed]

19. Min, H.K.; Choi, H.W.; Kim, K.H. Thickness dependence of $\mathrm{WO}_{3-\mathrm{x}}$ thin films for electrochromic device application. Mol. Cryst. Liquid Cryst. 2014, 598, 54-61.

20. Arfaoui, A.; Ouni, B.; Touihri, S.; Mannoubi, T. Investigation into the optoelectrical properties of tungsten oxide thin films annealed in an oxygen air. Mater. Res. Bull. 2014, 60, 719-729. [CrossRef]

21. Szilágyi, I.M.; Santala, E.; Heikkilä, M.; Kemell, M.; Nikitin, T.; Khriachtchev, L.; Räsänen, M.; Ritala, M.; Leskelä, M. Thermal study on electrospun polyvinylpyrrolidone/ammonium metatungstate nanofibers: Optimising the annealing conditions for obtaining $\mathrm{WO}_{3}$ nanofibers. J. Therm. Anal. Calorim. 2011, 105, 73. [CrossRef]

22. Badilescu, S.; Ashrit, P.V. Study of sol-gel prepared nanostructured $\mathrm{WO}_{3}$ thin films and composites for electrochromic applications. Solid State Ion. 2003, 158, 187-197. [CrossRef]

23. Zou, Y.S.; Zhang, Y.C.; Lou, D.; Wang, H.P.; Gu, L.; Dong, Y.H.; Dou, K.; Song, X.F.; Zeng, H.B. Structural and optical properties of $\mathrm{WO}_{3}$ films deposited by pulsed laser deposition. J. Alloy Compd. 2014, 583, 465-470. [CrossRef]

24. Haro-Poniatowski, E.; Jouanne, M.; Morhange, J.F.; Julien, C.; Diamant, R.; Fernández-Guasti, M.; Fuentes, G.A.; Alonso, J.C. Micro-raman characterization of $\mathrm{WO}_{3}$ and $\mathrm{MoO}_{3}$ thin films obtained by pulsed laser irradiation. Appl. Surf. Sci. 1998, 127-129, 674-678. [CrossRef]

25. Chai, Y.; Tam, C.W.; Beh, K.P.; Yam, F.K.; Hassan, Z. Effects of thermal treatment on the anodic growth of tungsten oxide films. Thin Solid Films 2015, 588, 44-49. [CrossRef]

26. Badot, J.C.; Beluze, L.; Dubrunfaut, O. Particle size effect on the electronic conductivity of electroactive $\mathrm{Li}_{\mathrm{x}} \mathrm{WO}_{3} \cdot \mathrm{H}_{2} \mathrm{O}$ powders: A study from $10^{3}$ to $10^{10} \mathrm{~Hz}$. J. Phys. Chem. C 2009, 112, 14549-14554. [CrossRef]

27. Faughnan, B.W.; Crandall, R.S.; Lampert, M.A. Model for the bleaching of $\mathrm{WO}_{3}$ electrochromic films by an electric field. Appl. Phys. Lett. 1975, 27, 275-277. [CrossRef] 
28. Srivastava, A.K.; Deepa, M.; Singh, S.; Kishore, R.; Agnihotry, S.A. Microstructural and electrochromic characteristics of electrodeposited and annealed $\mathrm{WO}_{3}$ films. Solid State Ion. 2005, 176, 1161-1168. [CrossRef]

29. Koo, B.R.; Ahn, H.J. Fast-switching electrochromic properties of mesoporous $\mathrm{WO}_{3}$ films with oxygen vacancy defects. Nanoscale 2017, 9, 17788-17793. [CrossRef] [PubMed] 